\title{
Penerapan Permainan Tebak Gambar dan Huruf untuk Meningkatkan Kemampuan Berbahasa Anak Kelompok A1 TK Negeri Pakunden 1 Kota Blitar
}

\author{
Siti Nur Indah Budiarti \\ TK Negeri Pakunden 1 Kota Blitar, Indonesia \\ Email: nurindahbudiarti31@gmail.com
}

\begin{abstract}
Abstrak: Penelitian in bertujuan untuk meningkatkan kemampuan anak TK dalam berbahasa. Kemampuan anak dalam berbahasa bisa didukung salah satunya dengan metode pembelajaran yang sesuai dan diminati anakanak. Oleh karena itu, penelitian ini menggunakan permainan tebak gambar dan huruf sebagai media pembelajaran yang menarik. Subjek pada penelian ini yaitu anak-anak kelompok A1 TK Negeri Pakunden Kota Blitar yang berjumlah 15 anak. Penelitian ini termasuk dalam Penelitian Tindakan Kelas yang dilakukan dalam dua siklus. Pada tiap-tiap siklus terdapat beberapa tahap seperti perencanaan, pelaksanaan, pengamatan dan refleksi. Untuk pengumpulan data, peneliti melakukan beberapa teknik seperti penugasan, observasi dan dokumentasi.

\begin{tabular}{l}
\hline Tersedia Online di \\
\hline http://journal.unublitar.ac.id/pendidi \\
\hline kan/index.php/Riset_Konseptual \\
\hline Sejarah Artikel \\
\hline Diterima pada : 05-04-2020 \\
Disetuji pada : 24-04-2020 \\
Dipublikasikan pada : 30-04-2020 \\
\hline Kata Kunci: \\
\hline Anak kelompok A, kemampuan berbahasa, \\
permainan Tebak Gambar dan Huruf \\
DOI: \\
\hline http://doi.org/10.28926/riset_konseptual.v4i \\
2.217
\end{tabular}
Penelitian ini menggunakan lembar observasi, lembar penilaian dan dokumen foto pembelajaran sebagai instrumen penelitian. Hasil penelitian menunjukkan bahwa pada siklus 1 ketuntasan belajar sebesar $65 \%$ atau 7 anak yang belum berhasil. Pada tahap ini menggunakan media berupa papan flannel, gambar binatang dan kartu huruf. Pertemuan pada siklus II media yang digunakan yaitu 2 papan flannel, gambar binatang dan kartu huruf. Ketuntasan pada siklus 2 mengalami peningkatan menjadi 95\% atau 13 anak dapat dikatakan berhasil. Sehingga dapat disimpulkan bahwa penerapan permainan tebak gambar dan huruf dapat meningkatkan kemampuan bahasa anak kelompok A1 di TK Negeri Pakunden Kota Blitar.
\end{abstract}

\section{PENDAHULUAN}

Pendidikan pada anak usia dini dikatakan sebagai pendidikan yang penting dan sangat mendasar. Pada usia inilah anak sedang mengalami golden age (masa emas) yang apabila pada masa tersebut anak diberikan stimulasi yang tepat akan menjadi modal penting untuk perkembangan anak dikemudian hari. Masa ini memungkinakan anak-anak untuk belajar lebih cepat dan optimal termasuk dalam belajar bahasa. Tujuan dari pendidikan anak usia dini adalah mengoptimalkan dan menyeimbangkan seluruh aspek perkembangan anak (Depdiknas, 2009:1).

Untuk membantu anak dalam menguasai kemampuan berbahasa, guru atau pendidik perlu menciptakan media dan suasana kelas dalam kegiatan pembelajaran yang menarik. Kegiatan pembelajaran di TK harus dilaksanakan dengan cara menyenangkan sehingga tidak membebani anak. Oleh karena itu, pembelajaran dikemas dalam bentuk kegiatan bermain. Bermain adalah kegiatan yang terjadi secara alamiah pada anak (Putro, 2016:26). Bermain bermanfaat bagi anak-anak untuk dapat memahami dan mengungkapkan dunianya baik pada taraf berfikir maupun merasa. Bermain memberi anak perasaan menguasai (mastery) atau mampu mengendalikan hal-hal yang ada dalam dunianya, sedangkan menurut (Santrock, 2007:217) menyatakan bahwa bermain merupakan seluruh aktifitas anak termasuk bekerja, yang dapat perasaan senang dan merupakan metode bagaimana mereka mengenal dunia. 
Bermain tidak sekedar hobi tetapi lebih pada sebuah kebutuhan yang diperlukan anak seperti halnya makan, tidur, cinta, kasih sayang, dan sebagainya. Bermain juga dapat memberikan pengalaman yang menyenangkan yang dapat memotovasi anak untuk terus belajar.

Kegiatan bermain haruslah sepadan dengan kebutuhan dan tahap perkembangan anak. Pernyataan tersebut senada dengan pendapat yang diungkapkan oleh (Hurlock 1996:320) yang berpendapat bahwa bagi anak, bermain adalah kegiatan yang dilakukan untuk mendapatkan kesenangan dengan tanpa mempedulikan hasil akhir. Pelaksanaan kegiatan dalam pendidikan anak usia dini ditekankan pada kreatifitas dalam bentuk belajar sambil bermain. Diyakini bahwa bermain dapat memberikan dampak positif bagi perkembangan anak pada setiap aspeknya termasuk fisik dan psikis yang meliputi aspek moral dan nilai-nilai agama, sosial emosional, kognitif, fisik motorik dan bahasa. Oleh karena itu, bermain sangat efektif sebagai suatu pendekatan dalam kegiatan belajar pendidikan prasekolah.

Berdasar hasil observasi dan wawancara yang dilakukan di TK Negeri Pakunden I Kota Blitar yang terletak di Jl Bengawan Solo Kelurahan Pakunden Kecamatan Sukorejo Kota Blitar pada hari Selasa tanggal 12 Maret 2019, diperoleh data bahwa kelas A1 berjumlah 15 anak. Permasalahan yang terjadi di TK Negeri Pakunden I untuk kelas $A 1$ yaitu perkembangan bahasa anak masih belum optimal terlihat dari $75 \%$ dari jumlah seluruh anak atau 10 dari 15 anak mengalami kesulitan merangkai huruf. Saat pembelajaran berlangsung masih terdapat pula anak yang enggan memberikan pertanyaan dan jawaban untuk dan dari guru. Hanya beberapa anak saja yang aktif dalam pelajaran. Bedasarkan dari hasil wawancara kepada Ibu Peni Pratiwi selaku guru kelompok A1 TK Negeri Pakunden I Kel. Pakunden Kec. Sukorejo Kota Blitar, diperoleh data bahwa anak sudah mampu menirukan kalimat sederhana, menebali huruf, menjiplak huruf dan mengenal huruf namun kemampuan anak untuk merangkai huruf masih kurang optimal. Hal ini disebabkan karena metode yang kurang menarik dan monoton serta kurangnya media pembelajaran yang menarik dan melibatkan anak dalam pembelajaran. Selama ini dalam pembelajaran merangkai huruf guru hanya melakukan dikte saja, sehingga anak merasa bosan. Berdasarkan hasil pembelajaran guru kelas menunjukkan bahwa aspek perkembangan bahasa anak tidak dapat berkembang secara optimal.

Berdasarkan permasalahan yang terjadi tersebut, peran guru sebagai fasilitator sangat diperlukan. Guru diharuskan untuk lebih kreatif untuk membuat media pembalajaran dalam kegiatan bermain untuk mengoptimalkan aspek bahasa anak. Fasilitas tersebut adalah alat peraga/media yang digunakan sebagai sarana untuk pengenalan huruf pada anak melalui kegiatan bermain seraya belajar yang menarik perhatian anak, dekat dengan lingkungan anak, dan inovatif. Salah satunya adalah dengan permainan tebak gambar dan huruf, yaitu suatu kegiatan pembelajaran yang menekankan pada aktifitas membaca gambar melalui ciri-cirinya dan mencari huruf kemudian menyusunnya menjadi sebuah kata sesuai dengan gambar. Melalui permainan tebak gambar dan huruf, maka pendidik dapat melaksanakan aktifitas bermain aktif untuk meningkatkan kemampuan berbahasa anak dalam mengenal aksara.

\section{METODE}

Penelitian ini termasuk dalam penelitian tindakan kelas yang diikuti proses siklus. Penelitian jenis ini dikarenakan pada tujuan bahwa peneliti ingin mendeskripsikan hasil dari kegiatan yang bertujuan untuk meningkatkan kemampuan bahasa anak melalui permainan tebak gambar dan huruf. Penelitian ini dilakukan di TK Negeri Pakunden I Kel. Pakunden, yang beralamatkan di Jalan Bengawan Solo Nomor 64 Kel. Pakunden Kec. Sukorejo Kota Blitar. Subyek penelitian ini adalah anak kelompok A1 berjumlah 15 anak yang terdiri dari 8 anak laki-laki dan 7 anak perempuan. Menurut Kemmis \&McTaggart, (dalam Wiriaatmadja, 2006: 66) penelitian tindakan kelas ditunjukkan melalui beberapa tahap yang dinamis yang mana empat aspek, yaitu perencanaan, 
tindakan, observasi, dan refleksi. Teknik pengumpulan data dilaksanakan dengan cara Observasi, Dokumentasi, Penugasan (test). Sedangkan analisis data diawali dari mempelajari, menyelidiki, mengkaji, dan memeriksa data yang diperoleh dari hasil observasi. Analisis data dilaksanakan secara berlanjut pada setiap siklus dengan pengolahan data. Pelaksanaan siklus I dilaksanakan pada hari Senin, 8 April 2019. Tema yang diajarkan pada siklus I ini adalah Binatang dengan sub tema binatang ternak. Selama kegiatan berlangsung, peneliti didampingi oleh guru kelas kelompok A1 yaitu ibu Peni Pratiwi yang membantu peneliti mengamati kejadian yang ada selama kegiatan berlangsung.

\section{Hasil Observasi Penelitian Siklus I}

\section{HASIL DAN PEMBAHASAN}

Peneliti meneliti aspek perkembangan bahasa dengan permainan tebak gambar dan huruf di TK Negeri Pakunden 1. Adapun hasil dari penelitian tersebut dapat dilihat pada tabel 1 tentang kemampuan bahasa anak dalam permainan tebak gambar dan huruf.

Tabel 1. kemampuan bahasa anak dalam permainan tebak gambar dan huruf

\begin{tabular}{|c|c|c|c|c|c|c|}
\hline \multirow[t]{2}{*}{ No } & \multirow{2}{*}{$\begin{array}{l}\text { Nama } \\
\text { Anak }\end{array}$} & \multicolumn{3}{|l|}{ Indikator } & \multirow{2}{*}{$\begin{array}{l}\text { Skor } \\
\text { tiap } \\
\text { anak }\end{array}$} & \multirow{2}{*}{$\begin{array}{l}\text { Keteran } \\
\text { gan }\end{array}$} \\
\hline & & $\begin{array}{l}\text { Melakukan 2-3 } \\
\text { perintah secara } \\
\text { berurutan }\end{array}$ & $\begin{array}{l}\text { Menyebutkan } \\
\text { nama benda } \\
\text { yang } \\
\text { diperlihatkan }\end{array}$ & \begin{tabular}{lr} 
Menyebutkan & tulisan \\
sederhana & dengan \\
simbol yang & \multicolumn{1}{c}{ yanglambangkannya }
\end{tabular} & & \\
\hline 1 & Adhe & 2 & 3 & 4 & 75 & Baik \\
\hline 2 & Adin & 3 & 4 & 3 & 83 & $\begin{array}{c}\text { Sangat } \\
\text { baik }\end{array}$ \\
\hline 3 & Adi & 2 & 4 & 3 & 75 & Baik \\
\hline 4 & Bimbi & 1 & 2 & 2 & 42 & Kurang \\
\hline 5 & Bella & 1 & 3 & 2 & 50 & Kurang \\
\hline 6 & Dian & 3 & 2 & 4 & 75 & Baik \\
\hline 7 & Dika & 2 & 4 & 3 & 75 & Baik \\
\hline 8 & Dwi & 3 & 2 & 4 & 75 & Baik \\
\hline 9 & Edo & 3 & 3 & 3 & 75 & Baik \\
\hline 10 & Farel & 2 & 2 & 2 & 50 & Kurang \\
\hline 11 & Gina & 2 & 4 & 3 & 75 & Baik \\
\hline 12 & Irfan & 4 & 4 & 4 & 100 & $\begin{array}{c}\text { Sangat } \\
\text { baik }\end{array}$ \\
\hline 13 & Kiki & 3 & 4 & 3 & 83 & Baik \\
\hline 13 & Mimi & 1 & 2 & 3 & 50 & Kurang \\
\hline 15 & Puri & 3 & 3 & 3 & 75 & Baik \\
\hline 16 & Rena & 1 & 2 & 2 & 42 & Kurang \\
\hline 17 & Sukma & 2 & 1 & 3 & 50 & Kurang \\
\hline 18 & Tina & 2 & 4 & 4 & 83 & Baik \\
\hline 19 & Tesa & 4 & 3 & 4 & 92 & $\begin{array}{c}\text { Sangat } \\
\text { baik }\end{array}$ \\
\hline 20 & Yesa & 1 & 2 & 2 & 42 & Kurang \\
\hline \multicolumn{5}{|c|}{ Jumlah } & 1367 & $\begin{array}{l}13 \text { anak } \\
\text { tuntas }\end{array}$ \\
\hline
\end{tabular}


Rata-rata

\begin{tabular}{|l|l|}
\hline 68,35 & \\
\hline $68.4 \%$ & $65 \%$ \\
\hline
\end{tabular}

Berdasarkan tabel 1 dapat dilihat bahwa penelitian siklus I dapat dilihat bahwa anak yang tuntas dalam kemampuan bahasa 13 anak (65\%), sedangkan 7 anak (35\%) yang kurang tuntas.Sehingga hasil penelitian pada siklus I ini masih belum tuntas dan dilanjutkan lagi ke siklus II.

Refleksi diperoleh dari guru kelas dan peneliti pada saat mengamati kemampuan anak pada saat permainan. Refleksi dilakukan dengan cara mendiskusikan tindakan yang sudah dilaksanakan, yaitu1) menganalisis pelaksanaan permainan Tebak Gambar dan Huruf yang sudah dilaksanakan, 2) mendiskusikan kesesuaian dari perencanaan kegiatan dengan hasil pelaksanaan, 3)memikirkan solusi dari kekurangan, 4)hambatan dan kelebihan yang ada saat pelaksanaan kegiatan. Selanjutnya hasil diskusi ini akan dijadikan acuan untuk memperbaiki dan merencanakan tindakan berikutnya, yaitu pada siklus II.

Hasil Refleksi pada siklus I dapat dikemukakan beberapa kesimpulan yang merupakan hasil penelitian, antara lain: 1) Pelaksanaan penerapan permainan Tebak Gambar dan Huruf dalam meningkatkan kemampuan bahasa, strategi yang digunakan hanya memberi tugas pada anak sehingga anak kurang antusias,2) permainan sebaiknya dilakukan dengan berpasangan yaitu dengan 2 anak dengan dua media, hal ini dimaksudkan agar waktu tidak terbuang lama dan anak tidak terlalu lama menunggu giliran bermain.Kelebihan pada siklus 1 adalah 1) guru dengan mudah melihat dan menilai anak yang tuntas maupun yang belum tuntas dalam permainan tebak gambar dan huruf, 2) tempat yang digunakan dalam permainan tidak terlalu lebar.

\section{Hasil Penelitian Siklus II}

Tabel 2. kemampuan bahasa anak dalam permainan tebak gambar dan huruf

\begin{tabular}{|c|c|c|c|c|c|c|}
\hline \multirow[t]{2}{*}{ No } & \multirow[t]{2}{*}{ Nama Anak } & \multicolumn{3}{|c|}{ Indikator } & \multirow{2}{*}{$\begin{array}{l}\text { Skor } \\
\text { tiap } \\
\text { anak }\end{array}$} & \multirow[t]{2}{*}{ Ket } \\
\hline & & $\begin{array}{l}\text { Melakuk-an } \\
2-3 \text { perintah } \\
\text { secara } \\
\text { berurutan }\end{array}$ & $\begin{array}{l}\text { Menyebutkan } \\
\text { nama benda } \\
\text { yang diperli- } \\
\text { hatkan }\end{array}$ & $\begin{array}{l}\text { Menyebutkan } \\
\text { tulisan } \\
\text { sederhana } \\
\text { dengan simbol } \\
\text { yang } \\
\text { melambangkan } \\
\text { nya }\end{array}$ & & \\
\hline 1 & Adhe & 3 & 4 & 4 & 92 & Sangat baik \\
\hline 2 & Adin & 4 & 4 & 4 & 100 & Sangat baik \\
\hline 3 & Adi & 4 & 4 & 4 & 100 & Sangat baik \\
\hline 4 & Bimbi & 1 & 2 & 2 & 42 & Kurang \\
\hline 5 & Bella & 4 & 3 & 3 & 83 & Baik \\
\hline 6 & Dian & 4 & 4 & 4 & 100 & Sangat baik \\
\hline 7 & Dika & 4 & 3 & 4 & 92 & Sangat baik \\
\hline 8 & Dwi & 4 & 4 & 4 & 100 & Sangat baik \\
\hline 9 & Edo & 4 & 4 & 4 & 100 & Sangat baik \\
\hline 10 & Farel & 3 & 2 & 4 & 75 & Baik \\
\hline 11 & Gina & 4 & 2 & 4 & 83 & Baik \\
\hline
\end{tabular}




\begin{tabular}{|c|c|c|c|c|c|c|}
\hline 12 & Irfan & 4 & 4 & 4 & 100 & Sangat baik \\
\hline 13 & Kiki & 4 & 4 & 4 & 100 & Sangat baik \\
\hline 13 & Mimi & 3 & 2 & 4 & 75 & Baik \\
\hline 15 & Puri & 3 & 3 & 3 & 75 & Baik \\
\hline 16 & Rena & 3 & 4 & 3 & 83 & Baik \\
\hline 17 & Sukma & 4 & 3 & 3 & 83 & Baik \\
\hline 18 & Tina & 4 & 3 & 4 & 92 & Sangat baik \\
\hline 19 & Tesa & 4 & 3 & 4 & 92 & Sangat baik \\
\hline 20 & Yesa & 4 & 3 & 4 & 92 & Sangat baik \\
\hline \multicolumn{5}{|c|}{ Jumlah } & 1759 & 19 anak tuntas \\
\hline \multicolumn{5}{|c|}{ Rata-rata } & 87,95 & 0.95 \\
\hline \multicolumn{5}{|c|}{ Persentase } & $88 \%$ & $95 \%$ \\
\hline
\end{tabular}

Berdasarkan tabel 2 dapat diketahui bahwa tedapat peningkatan yang terjadi pada siklus II. Pada tabel 1 dan tabel 2 dapat dilihat bahwa anak yang tuntas dalam kemampuan bahasa meningkat yang semula hanya 13 anak (65\%) menjadi 19 anak (95\%).

Perbandingan ketuntasan hasil belajar siswa pada siklus I dan siklus II dapat dilihat pada tabel 3 dibawah ini.

Tabel 3. Perbandingan ketuntasan hasil belajar siswa pada siklus I dan siklus II

\begin{tabular}{llll}
\hline No. & Aspek yang dinilai & $\begin{array}{l}\text { Keberhasilan } \\
\text { Siklus I }\end{array}$ & $\begin{array}{l}\text { Keberhasilan } \\
\text { Siklus II }\end{array}$ \\
\hline 1. & Kemampuan bahasa anak & $65 \%$ & $95 \%$ \\
\hline
\end{tabular}

Berdasarkan tabel 3 diketahui bahwa rata-rata kualitas belajar siswa pada siklus I secara klasikal masuk dalam kategori bintang 2.Pada siklus II kualitas aktivitas belajar anak meningkat dengan taraf keberhasilan dengan kategori bintang 4.

Pada bagian refleksi siklus II akan dikemukakan beberapa hal tentang hasil proses pelaksanaan pembelajaran antara lain:

a. Guru sudah membuat rencana kegiatan harian $(\mathrm{RKH})$ dengan baik dan semua kegiatan dapat dilaksanakan dengan baik.

b. Anak merasa senang dengan kegiatan yang dilaksanakan oleh guru. Tidak ada anak yang bosan dan bermain sendiri.

c. Peningkatan kemampuan menebak gambar dan merangkai huruf sudah terlihat pada pembelajaran siklus II, karena permainan tebak gambar dan hurufmerupakan permainan untuk melatih kemampuan bahasa anak.

d. Berdasarkan hasil unjuk kerja anak menunjukkan bahwa kemampuan bahasa anak dalam permainan mengalami peningkatan dari sikus I sebesar $65 \%$ meningkat menjadi $95 \%$.

Hasil penelitian pada siklus I dan siklus II terjadi peningkatan hasil belajar anak, pada siklus I kemampuan anak rata-rata mencapai $65 \%$ dan pada siklus II kemampuan anak mengalami rata-rata peningkatan mencapai 95\%.Siklus I dan siklus II kemampuan berbahasa anak mengalami peningkatan sebesar $30 \%$. Hal ini membuktikan bahwa penerapan permainan tebak dan huruf dapat meningkatkan kemampuan berbahasa anak kelompok A1 TK Negeri Pakunden I Kel.Pakunden Kec.Sukorejo Kota Blitar.

Anak Usia 4-5 tahun memiliki kemampuan berbahasa sebagai berikut: a) memiliki berbagai perbendaharaan kata kerja, kata sifat, kata keadaan, kata tanya dan kata sambung, b) menunjukkan pengertian dan pemahaman tentang sesuatu, c) mampu mengungkapkan pikiran, perasaan dan tindakan dengan menggunakan kalimat sederhana, d) mampu membaca dan mengungkapkan sesuatu melalui gambar. 
Perkembangan potensi tersebut muncul ditandai oleh berbagai gejala seperti senang bertanya dan memberikan informasi tentang sesuatu hal dan berbicara (Depdiknas, 2007: 3). Melalui permainan tebak gambar dan huruf diharapkan perkembangan bahasa anak berkembang secara maksimal.

Adapun Langkah-langkah permainan tebak gambar dan huruf yaitu :

a. Guru memberi/menempel gambar pada papan yang telah ditutupi dengan kain flanel yang berbeda warna.

b. Anak disuruh menyebutkan / memilih warna penutup yang ingin dibuka, setelah anak memilih kain flanel yang iangin dibuka, guru menjelaskan ciri-ciri tentang binatang tersebut agar anak mampu menjawab binatang apakah itu.

c. Setelah anak mampu menyebutkan nama binatang, anak disuruh mengambil huruf lalu merangkainya di papan flanel, tepatnya dibawah gambar.

d. Setelah huruf selesai dirangkai, anak disuruh membaca huruf yang baru dirangkainya.

Langkah-langkah pada permainan tebak gambar dan huruf ini sesuai dengan langkahlangkah menurut Rifqiyah yaitu :

1. Guru mempersiapkan media

2. Guru bercakap-cakap tentang tema

3. Guru menunjukkan media

4. Guru menjelasakan media

5. Anak menebak gambar

6. Anak mencari huruf

7. Anak menyusun huruf

8. Anak membaca huruf

Kemampuan bahasa diperoleh secara bertahap dan sistematis sesuai dengan perkembangannya. Menurut Putro (2016:23) kemampuan berbahasa pada anak berkembang dari simpel ke kompleks. Berdasarkan pendapat tersebut maka dapat dikatakan permainan tebak gambar dan huruf dapat diterapkan untuk mebantu meningkatkan bahasa anak. Pembelajaran dikemas dalam sebuah permainan yang mudah dan menyenangkan yaitu, mulai dari tahap menebak gambar melalui ciri-ciri, membaca gambar dan merangkai huruf. Permainan tebak gambar dan huruf dipilih sebagai alternatif untuk meningkatkan bahasa dan merangsang keingin tahuan anak sesuai dengan pendapat Eliyawati (2005: 2) bahwa anak memiliki rasa ingin tahu yang tinggi terhadap hal-hal baru yang mereka temui.

Penerapan permainan Tebak Gambar dan Huruf dalam meningkatkan kemampuan bahasa anak kelompok $A$ menunjukkan peningkatan. Permainan ini diperuntukkan pada kelompok A di TK Negeri Pakunden I Kota Blitar yang dilakukan selama dua siklus dengan dua kali pertemuan. Pada siklus I pertemuan pertama, anakanak kurang antusias dalam permainan, karena strategi yang digunakan seakan memberi tugas pada anak (kurang menyenangkan) dan media yang digunakan hanya satu sehingga waktu banyak terbuang.Pada siklus II dilakukan dengan menggunakan dua media dan dua anak, pada siklus II ini dua anak diminta adu cepat dan tepat dalam menebak gambar dan merangkai huruf. Siklus II ini kemampuan anak dalam kegiatan sudah baik jika dibandingkan pada siklus I. Permainan Tebak Gambar dan Huruf yang dilakukan oleh anak sudah sesuai dengan kriteria yang dinilai dalam kemampuan bahasa yaitu anak sudah mencapai rentang nilai $70 \%$.

Tahap selanjutnya setelah memaparkan hasil penelitian dan membandingkannya, seperti tampak pada bagian sebelumnya yang terdapat dalam hasil penelitian. Penjelasan mengenai sistematika kegiatan penerapan permainan Tebak Gambar dan Huruf dalam penelitian tindakan kelas ini dimulai dengan mempersiapkan perangkat mengajar berupa $\mathrm{RKH}$, RPP, dan media yang akan digunakan. Setelah persiapan untuk pembelajaran sudah lengkap, pendidik dan peneliti melaksanakan tugas masing-masing sesuai RPP.Peneliti menjadi pengamat dan pendidik sebagai pelaksanaan kegiatan.Kegiatan dilaksanakan oleh anak dengan 
bimbingan pendidik, dan peneliti memberikan skor penilaian pada setiap anak. Setelah kegiatan selesai, maka data selama proses kegiatan akan digunakan untuk memproses data selanjutnya.

Dari data yang sudah disajikan dapat diketahui bahwa peningkatan terjadi pada setiap anak. Dapat diketahui bahwa penerapan permainan Tebak Gambar dan Huruf dapat meningkatkan kemampuan bahasa anak kelompok A di TK Negeri Pakunden I Kota Blitar pada semester II tahun pelajaran 2019/2020, ini dapat dilihat adanya peningkatan nilai anak dari setiap indikator yang dinilai.

Penelitian yang dilaksanakan melalui permainan Tebak Gambar dan Huruf, ternyata dapat meningkatkan kemampuan bahasa anak, tapi dalam penelitian pada kelompok A TK Negeri Pakunden I Kota Blitar masih terdapat 1 anak yang perkembangan kemampuannya lambat dan kurang konsentrasi dalam kegiatan.

Pada penelitian siklus I peningkatan kemampuan bahasa anak melalui permainan Tebak Gambar dan Huruf sudah mengalami peningkatan, yaitu dengan jumlah rata-rata $68,4 \%$ dengan ketuntasan klasikal sebesar $65 \%$. Sedangkan pada siklus II kemampuan anak sudah lebih baik dan optimal daripada siklus I, hal ini ditandai dengan adanya peningkatan jumlah rata-rata anak yaitu sebesar $86 \%$ dengan ketuntasan secara klasikal 95\%. Melalui analisis secara kuantitatif, kemampuan bahasa anak melalui permainan Tebak Gambar dan Huruf dapat meningkatkan kualitas dan hasil pembelajaran yang ditandai dengan terjadinya peningkatan skor anak pada setiap indikator yang dinilai dan mampu mencapai ketuntasan minimal yaitu $70 \%$ secara klasikal.

Berdasarkan penelitian melalui permainan tebak gambar dan huruf dapat meningkatkan kemampuan berbahasa anak. Hal ini sesuai dengan tujuan dari permainan tebak gambar dan huruf yang diungkapkan oleh Jamil (Wahyuni, 2010: 38) yaitu :(1) melatih kepekaan pancaindra anak dalam memahami suatu gambar melalui ciri-ciri, (2) melatih kemampuan konsentrasi anak dalam menghadapai suatu masalah, (3) mengenalkan berbagai huruf, merangkai huruf dengan cara yang menyenangkan, (4) memberikan pengalaman belajar langsung kepada anak dengan bermain aktif.

Permainan tebak gambar dan huruf untuk mengembangkan bahasa sesuai dengan Permainan bersifat Konstruktif menurut Hurlock (1993: 332) yaitu bentuk bermain dimana anak-anak menggunakan bahan untuk membuat sesuatu yang bukan untuk tujuan bermanfaat melainkan lebih ditujukan bagi kegembiraan yang diperolehnya dari membuatnya.

\section{KESIMPULAN}

Peningkatan pembelajaran melalui permainan tebak gambar dan huruf dapat meningkatkan kemampuan bahasa anak, yang achirnya kemampuan bahasa anak dapat berkembang secara maksimal. Hal ini ditandai dengan meningkatnya skor keberhasilan anak pada siklus 2. Pada siklus I penilaian kemampuan bahasa mencapai skor rata-rata 65\%, dan siklus II peningkatan mencapai 95\%. Selain itu anak juga menunjukkan rasa senang dan antusias pada saat bermain, danpada siklus ke 2 , anak juga tidak merasa bosan untuk menunggu giliran bermain.

\section{DAFTAR RUJUKAN}

Depdiknas. 2007. Pedoman Pembelajaran permainan berhitung permulaan di taman kanak kanak. Jakarta Dikdasmen

Depdiknas. 2009. Permendiknas No. 58/2009 tentang standar Tingkat Pencapaian Perkembangan. Jakarta: Depdikbud

Eliyawati, C. 2005. Pemilihan dan Pengembangan Sumber Belajar Untuk Anak Usia Dini. Jakarta: Departemen Pendidikan Nasional.

Hurlock, E. B. 2008. Perkembangan Anak. (Alih bahasa: Agus Dharma). Jakarta: Erlangga. 
Putro. 2016. Mengembangkan Kreativitas Anak Melalui Bermain, Universitas Islam Negeri (UIN) Sunan Kalijaga Yogyakarta, Indonesia. Jurnal Aplikasi IImu-ilmu Agama. Vol. 16 No. 1, 2016

Santrock, J. W. 2007. Perkembangan Anak. Penerjemah: Mila Rahmawati dan Anak Kuswanti. Jakarta: Erlangga

Wiriaatmadja, R. 2006. Metode Penelitian Tindakan Kelas. Bandung: PT. Remaja Rosdakarya 